\title{
Genetic Variants in Interleukin-10 Gene Association with Susceptibility and Cervical Cancer Development: A Case Control Study
}

\author{
Pushpendra D. Pratap ${ }^{1} \quad$ Syed Tasleem Raza ${ }^{1} \quad$ Ghazala Zaidi $^{2} \quad$ Shipra Kunwar $^{3}$ Sharique Ahmad ${ }^{4}$ \\ Mark Rector Charles ${ }^{1}$ Ale Eba ${ }^{1}$ Muneshwar Rajput ${ }^{1}$
}

${ }^{1}$ Central Research Laboratory, Molecular Diagnostic Unit, Department of Biochemistry, Era's Lucknow Medical College, Era University, Lucknow, Uttar Pradesh, India

2 Department of Allied Health Sciences, Era University, Lucknow, Uttar Pradesh, India

${ }^{3}$ Department of Obstetrics \& Gynecology, Era University, Lucknow, Uttar Pradesh, India

${ }^{4}$ Department of Pathology, Era's Lucknow Medical College, Era University, Lucknow, Uttar Pradesh, India
Address for correspondence Syed Tasleem Raza, PhD, Department of Biochemistry, Era's Lucknow Medical College, ERA University, Lucknow 226003, Uttar Pradesh, India (e-mail: tasleem24@gmail.com).

Glob Med Genet 2022;9:129-140.

\begin{abstract}
Keywords

- human papillomavirus

- cervical cancer

- gene polymorphism

Objectives Cervical cancer (CC) is one of the most destructive disease caused by persistent HPV infection which affects women worldwide, especially in developing countries. The genetic basis of host immune response especially cytokine function has been shown to influence CC susceptibility. Studies have demonstrated that IL-10 gene polymorphism have been associated with numerous malignancies, but in context to CC results were inconclusive. Though, aim of our study to investigate the association between IL-10 -1082A/G and -819C/T promoter polymorphism and CC susceptibility. Material and Methods This study comprised 192 women with CC and 200 controls. HPV detection was done by RT-PCR and genotyping was assessed through PCR-RFLP method. Serum concentration of IL-10 measured by ELISA.

Results Women with AG and AG+GG genotypes of IL-10 -1082A/G had two-fold increased risk of CC [OR, $2.35(95 \% \mathrm{Cl}, 1.54-3.58), p=0.005$ ], [OR, $2.03(95 \% \mathrm{Cl}, 1.36-$ $3.04), p=0.0005]$ compared to controls. Women with $G$ allele of $-1082 \mathrm{~A} / \mathrm{G}$ polymorphism had linked with CC susceptibility [OR, 1.39 (95\% Cl, 1.02-1.88), $p=0.036$ ] compared to controls. No significant difference was found between patients and controls in the genotype or allele frequencies of IL-10 -819C/T polymorphism [OR, 1.00 (95\% Cl, 0.63-1.58), $p=0.99$ ]. The level of serum concentration of IL-10 was significantly higher in cases compared to controls.

Conclusion These findings help to understand that polymorphism of IL-10 -1082A/G gene is associated with increased risk of CC development and can serve as a marker of genetic susceptibility to CC.
\end{abstract}

received

November 27, 2021

accepted

December 29, 2021
DOI https://doi.org/

$10.1055 / \mathrm{s}-0042-1743262$.

ISSN 2699-9404. (c) 2022. The Author(s).

This is an open access article published by Thieme under the terms of the Creative Commons Attribution License, permitting unrestricted use, distribution, and reproduction so long as the original work is properly cited. (https://creativecommons.org/licenses/by/4.0/)

Georg Thieme Verlag KG, Rüdigerstraße 14, 70469 Stuttgart, Germany 


\section{Introduction}

Cervical cancer (CC) is one of the most fatal malignancies among females and is recognized as the second most common cancer globally. ${ }^{1}$ Overall, it is recognized as the fourth most common type of malignancy and frequently occurs in the lower end of the uterine cervix, affecting normal cervix epithelial tissues and causing aberrant changes in the deeper tissues. $^{2-4}$ CC affects more than half a million women annually, culminating in more than 570,000 diagnosis and 300,000 fatalities worldwide as per WHO reports. Interestingly, $90 \%$ of CC patients emerge within low- and middleincome countries. ${ }^{5,6}$ There are $\sim 365.71$ million women in India over the age of 15 years who are at risk of CC. According to existing evidence, around 132,000 new cases of CC are diagnosed each year in India, with 74,000 fatalities, accounting for nearly one-third of $\mathrm{CC}$ deaths worldwide. Indian women have a $2.5 \%$ lifetime risk of CC and a $1.4 \%$ lifetime risk of mortality from CC. ${ }^{7}$

The human papillomavirus (HPV) is recognized to be the most common cause of CC in women, especially high-risk HPV subtypes HPV16 and HPV18. However, HPV infection is not always essential for the progression of this disease, as the majority of the patients (70-90\%) eradicate the virus within 1 to 2 years of initial diagnosis. ${ }^{8}$ Besides HPV, various other risk factors for CC development include timing of the first intercourse, early pregnancy, multiple pregnancies in a short period of time, multiple sexual partners, oral contraceptive pills, race or ethnicity, smoking habit, diet habits, parturition, family history of $\mathrm{CC}$, and inadequate socioeconomic circumstances. ${ }^{9,10}$ Furthermore significantly, evidence has demonstrated that genetic heredity is one of the most common intrinsic factors associated with the development of CCs, increasing the risk by $\sim 27 \% .{ }^{11,12} \mathrm{HPV}$-related epithelial transformation of the cervix, which is a crucial determinant for the development of cervical neoplasia, has been linked to genetic polymorphisms in various immune mediators. ${ }^{13}$

Through the activation of various immune components, such as cells and cytokines, the immune system plays a critical role in repressing or encouraging tumorigenesis. The modification of tumorigenesis appears to be associated with the antigen presentation response, which is downregulated in CC, resulting in humoral response and cellular response reduction. ${ }^{14}$ Regardless of the fact that HPV infection causes CC in a small percentage of infected women, there is a latent period after infection and before diagnosis of cancer, trying to demonstrate that cell-mediated immunity is a part of regular host immune activity controlled by cytokines, and cytokines' activities are extremely crucial for CC development. ${ }^{9}$ Variations in host genetic vulnerability and immunological responses have been linked to increased risk of HPV-related CC. ${ }^{15}$

Interleukin-10 (IL-10) is a multifunctional cytokine that is secreted by lymphocytes, monocytes, and other cells and has anti-inflammatory and immunosuppressive characteristics. ${ }^{16,17}$ IL-10 is found on human chromosome 1 (1q31$1 \mathrm{q} 32)$ and has five exons and four introns. ${ }^{18}$ Studies have shown that IL-10 is relevant to tumor egregiousness and mediates angiogenesis in tumor tissues. ${ }^{17}$ It has been established that IL-10 suppresses activated lymphocytes and macrophages from producing proinflammatory cytokines in these cells. ${ }^{19}$ It was reported that rs $1800896(-1082 \mathrm{~A} / \mathrm{G})$ was found to be related with pediatric postbronchiolitis asthma in a recent study of four single nucleotide polymorphisms (SNPs) in the IL-10 gene, including rs1800871 $(-819 \mathrm{C} / \mathrm{T}), 1,800,872(-592 \mathrm{C} / \mathrm{A})$, rs1800890 (-3575 T/A), and rs1800896 $(-1082 \mathrm{~A} / \mathrm{G}){ }^{20}$ According to a meta-analysis, rs1800872 may have a role in the development of smoking-related cancer susceptibility. ${ }^{17}$

IL-10 genetic variations have been associated with a greater risk of CC throughout many studies. For instance, a recent incident analysis in Chinese women demonstrated that the IL-10 rs1800872 polymorphism is associated with the severity of cervical neoplasia. ${ }^{21}$ Another study in the Chinese population explored the correlation between the IL10 gene polymorphisms rs 1800871 , rs1800872, and rs1800896, and concluded that rs1800871 potentially contributes to the risk of $\mathrm{CC}^{22} \mathrm{~A}$ meta-analysis in the Asian population, conducted by $\mathrm{Ni}$ et $\mathrm{al}^{23}$ found a significant correlation between the minor allele of rs 1800872 and enhanced cervical carcinogenesis recurrence. However, no association with the rs1800896 polymorphism was observed. rs 1800872 has also been associated with persons of Indian, ${ }^{24}$ Mexican, ${ }^{25}$ and Dutch ethnicities. ${ }^{26}$ The genetic polymorphism of IL-10 (-1082A/G) has also been linked to CC in Brazilian ${ }^{27}$ and Japanese women. ${ }^{28}$

The frequency and intensity of disease occurrences in different regions of the world may differ based on geographical and biological diversity, as well as ethnical differences in genetic makeup. Even within the same ethnicity or origin, differences can be observed. ${ }^{29,30}$ Therefore, we conducted the current case control study to determine the association of IL-10 SNPs rs1800870 (-1082A/G) and rs1800871 (-819C/T) polymorphisms with CC susceptibility.

\section{Material and Methods}

\section{Study Design}

\section{Patients and Sample Collection}

For this case control study, 392 patients were included, of which 192 patients were diagnosed with CC and confirmed by a pathologist based on histopathology and clinical features, and 200 control subjects were negative for cytological abnormalities with no history of cancer and infection, and free from any acute or chronic pathology. All the participants were recruited from the OPD, Department of the Obstetrics and Gynecology, ERA's Lucknow Medical College \& Hospital (ELMC\&H), Lucknow, Uttar Pradesh. All histopathologically confirmed CC cases were staged as per the International Federation of Gynecology and Obstetrics (FIGO) criteria. Institutional Ethics Committee gave their approval (Ref. No. ELMC \&H/2019/R_Cell/EC/169). The purpose and procedures of this study were explained and written informed consent was obtained from all participants. 


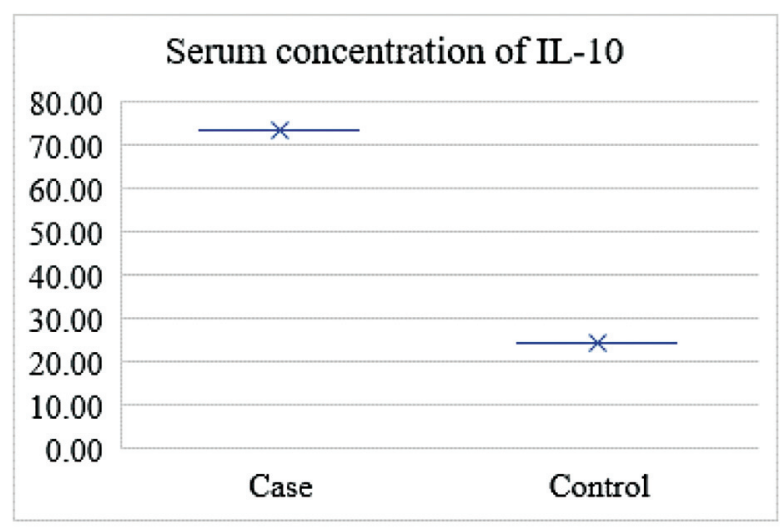

Fig. 1 Showing elevated serum concentration of IL-10 in cases versus controls.

All study participants underwent DNA analysis for IL-10 polymorphism genotyping. Each subject's peripheral blood was collected into tubes containing ethylenediaminetetraacetic acid (EDTA) and plain vials prior to radiation therapy and/or chemotherapy at the time of initial diagnosis. Each participant's blood and serum samples were kept at $-70^{\circ} \mathrm{C}$ until further use. Structured questionnaire was applied concerning sociodemographic characteristics reproductive as well as sexual behavior and clinical information was obtained from the hospital record section.

\section{Genomic DNA Extraction and Genotyping}

Genomic DNA from peripheral blood samples of each subjects was extracted using the PureLink Genomic DNA extraction kit according to manufacturer's instructions (Thermo Fisher Scientific). DNA concentration of all samples was measured by NanoDrop 2000c Spectrophotometer (Thermo Fisher Scientific) at $260 \mathrm{~nm}$ and purity was assessed through a $260 / 280$ ratio.

\section{Enzyme Linked Immunosorbent Assay (ELISA)}

The measurement of concentration of IL-10 in serum samples was assessed through enzyme-linked immunosorbent assay (ELISA) using Human IL-10 ELISA Kit (Diaclone, Cat. No.950.060.096) as per the manufacturer protocol (-Fig. 1). In brief, $100 \mu \mathrm{L}$ of samples, controls, and standard were added to the plate and incubated at room temperature for 1 hour. After three washes with washing buffer, $100-\mu \mathrm{L}$ streptavidin-HRP was added and incubated at room temperature for 30 minutes. The plate was washed three times with washing buffer and $100-\mu \mathrm{L}$ substrate solution was added for color development. After adding $100-\mu \mathrm{L}$ stop solution, optical density (OD) was measured and the results were recorded in picograms per milliliter $(\mathrm{pg} / \mathrm{mL})$.

\section{HPV Detection}

For HPV DNA extraction, tissue biopsy samples were collected in normal saline and extracted through HPV 16/18 RT-PCR kit (Liferiver, Shanghai) as per manufacturer protocol. DNA extraction buffer was supplied in the kit, which was thoroughly thawed and spun down in the centrifuge. The tissue

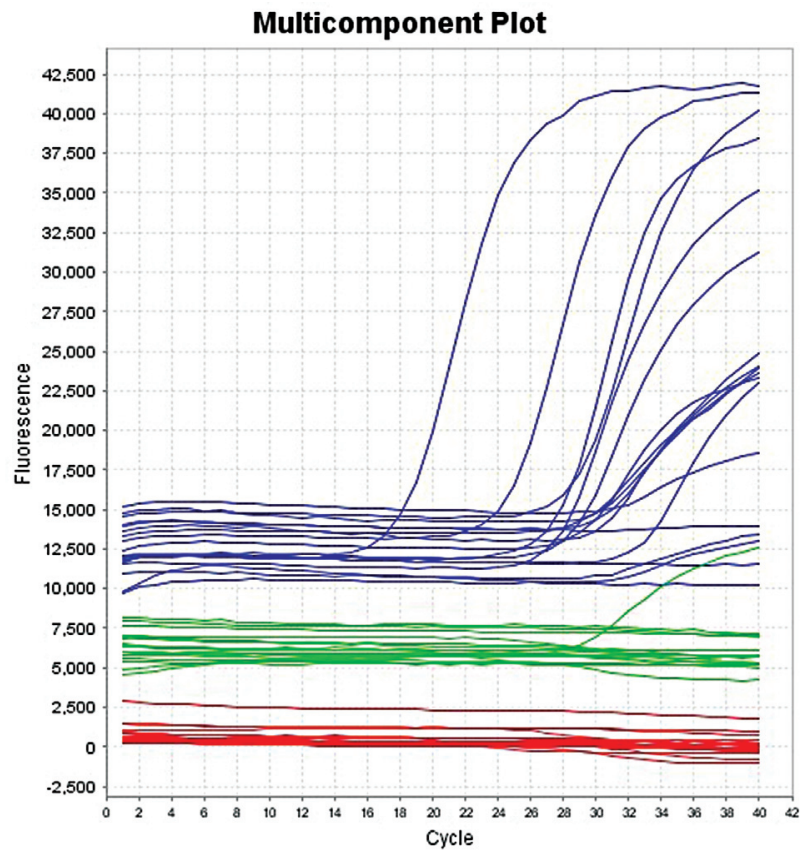

$\left[\begin{array}{l}\log s d \\ \square \mathrm{A} \square \mathrm{C} \square \mathrm{D} \square \mathrm{E} \square \mathrm{F} \square \mathrm{G} \square \mathrm{H}\end{array}\right.$

Fig. 2 Real-time polymerase chain reaction (PCR) multicomponent graph showing HPV 16 (blue line), HPV 18 (green line), and internal control (red line) expression in cases and control.

was crushed, mixed with $1 \mathrm{~mL}$ normal saline (NS), vortexed vigorously, and centrifuged at $13,000 \mathrm{rpm}$ for 5 minutes. The supernatant was discarded and the pellet was again mixed with $1 \mathrm{~mL} \mathrm{NS}$, and centrifuged at 13,000 rpm for 5 minutes. The supernatant was discarded, $50 \mu \mathrm{L}$ buffer was added, vortexed for 10 seconds, and incubated at $100^{\circ} \mathrm{C}$ for 10 minutes. After that, it was centrifuged for 5 minutes at $13,000 \mathrm{rpm}$ and the supernatant was collected, that is, the DNA was extracted, which can be used as a template for polymerase chain reaction (PCR).

Real-time PCR (RT-PCR) was performed in a $40-\mu \mathrm{L}$ reaction mixture (RM) containing $\sim 4 \mu \mathrm{L}$ of extracted DNA (template) and $36 \mu \mathrm{L}$ of master mix (MM). The MM for each reaction was prepared through pipetting $35 \mu \mathrm{L}$ of reaction mix (HPV serotype 16 and 18 reactions mix), $0.4 \mu \mathrm{L}$ of enzyme (DNA polymerase), and then $1 \mu \mathrm{L}$ of internal control (IC) ending up with a total of $36.4 \mu \mathrm{L}$ of MM. The RT-PCR cycling conditions included were initial one cycle at $37^{\circ} \mathrm{C}$ for 2 minutes, then one cycle denaturation at $94^{\circ} \mathrm{C}$ for 2 minutes, followed by 40 cycles at $93^{\circ} \mathrm{C}$ for 15 seconds, and at $60^{\circ} \mathrm{C}$ for 60 seconds. Amplified HPV16 and HPV18 DNA fragment detection was performed in fluorimeter channel FAM and HEX/VIC/JOE with the fluorescent quencher BHQ1 at $60^{\circ} \mathrm{C}$ (- Fig. 2).

\section{IL-10 -1082A/G Polymorphism Genotyping}

Genomic DNA from peripheral blood samples was used for detection of IL-10 -1082A/G polymorphism by multiplex PCR technique (MJ Mini Thermo Cycler, BioRad). Primers sequence used for IL-10 $-1082 \mathrm{~A} / \mathrm{G}$ gene amplification are as follows: the forward primers (5'-TCT GAA GAA GTC CTG ATG TCA CTG-3') and 

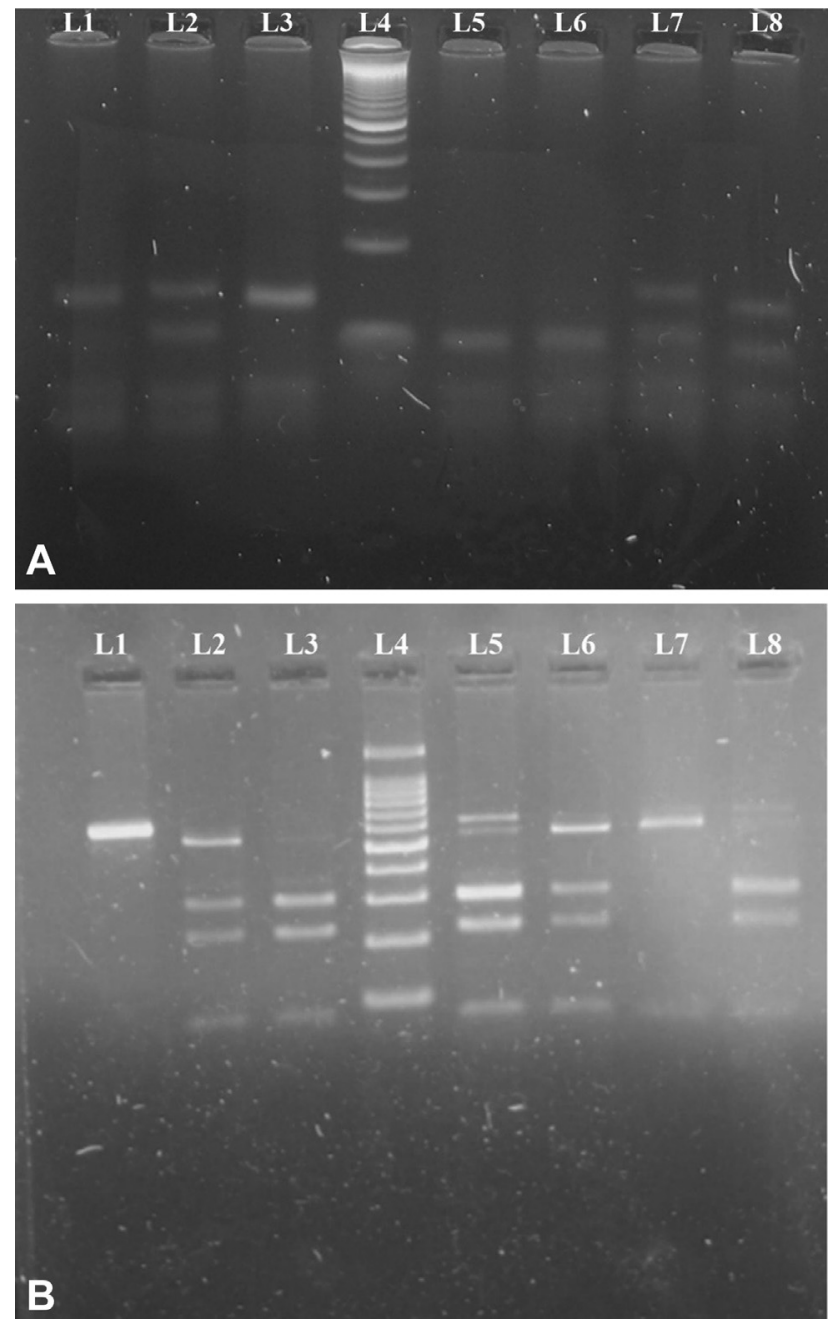

Fig. 3 (A) Agarose gel picture showing IL-10 -1082 genotypes lanes 1 and 3: AA genotype (138 bp, 58bp); lanes 2, 7, and 8: AG genotype (138 bp, $110 \mathrm{bp}$, and 58bp); lane 4: Molecular Marker $100 \mathrm{bp}$; lanes 5 and 6: GG genotype (110 bp, 58bp). (B) Agarose gel picture showing IL-10 -819 genotypes. Lane 1: UD (600 bp); lanes 2, 5, and 6: CT genotype (509 bp, 292 bp, 217 bp, 79 bp); lanes 3 and 8: CC genotype (292 bp, 217 bp, 79 bp); lane 4: Molecular Marker 100 bp; lane 7: TT genotype (509 bp, 79 bp).

reverse primers (5'-ACT TTC ATC TTA CCT ATC CCT ACT TCC ${ }^{\prime}$ ). PCR conditions were $10 \mathrm{pmol}$ of each primer, $2.5 \mathrm{mmol} / \mathrm{L} \mathrm{MgCl}_{2}$, $0.2 \mathrm{mmol} / \mathrm{L}$ of each dNTPs, 1 unit of Taq polymerase (Bioline Ltd., London, UK) along with $100 \mathrm{ng}$ of peripheral genomic DNA with annealing temperature of $55^{\circ} \mathrm{C}$.

The IL-10 - $1082 \mathrm{~A} / \mathrm{G}$ product amplification corresponds to a 196-bp fragment. The enzymatic restriction was assessed through restricted fragment length polymorphism (RFLP) using amplified product in the presence and using $2 \mathrm{U}$ of the restriction enzymes MnII (New England Biolabs, Beverly, Massachusetts, United States) and incubated at $37^{\circ} \mathrm{C}$ overnight. The products were analyzed by electrophoresis in a 3\% agarose gel stained with ethidium bromide (EtBr), and visualized under ultraviolet light. This enzyme cleaves the amplified fragment of DNA in the presence of adenine, producing fragments of 110 and $58 \mathrm{bp}$, and fragments of 110,58 , and $28 \mathrm{bp}$ in the presence of guanine allele (-Fig. 3A).

\section{IL-10 -819C/T Polymorphism Genotyping}

The IL-10 -819C/T polymorphism was performed by PCR followed by RFLP using specific set of primers, forward primer (5'-ATCCAAGACAACACTACTAA-3') and reverse primer (5'-TAAATATCCTCAAAGTTCC- $\left.3^{\prime}\right)$ to amplify a region of 509 bp of IL-10 containing the polymorphic locus. PCR conditions were $0.1 \mathrm{mM}$ of dNTPs, $0.25 \mathrm{uM}$ of each primer, $1.5 \mathrm{mM}$ of $\mathrm{MgCl}_{2}, 100 \mathrm{ng}$ of DNA, and $1 \mathrm{U}$ of Taq DNA polymerase along with an annealing temperature of $57^{\circ} \mathrm{C}$. The amplified products were submitted to enzymatic restriction with $2.5 \mathrm{U}$ of MaelII enzyme, at $55^{\circ} \mathrm{C}$ for 6 hours, for polymorphism analysis. The restriction fragments were electrophoresed on 3\% agarose gel stained with $\mathrm{EtBr}$, and visualized under ultraviolet light ( - Fig. 3B).

\section{Statistical Analysis}

All the differences in sociodemographic and categorical data between CC patients and controls were analyzed using contingency tables and chi-squared test ( $x 2$ test) and the values were expressed along with percentage. Age were tested for normality by Kolmogorov-Smirnov test and a non-normal distribution was assumed. Allele frequency was calculated as $[1(h+2 H)] / 2 N$, where $h$ represents the heterozygous genotype, $H$ is the homozygous genotype, and $N$ is the sample size for each population. Hardy-Weinberg equilibrium in CC patients and controls was tested using the $\chi^{2}$ test. Differences in the genotype frequencies between CC cases and controls were assessed by the $\chi^{2}$ test. The SPSS v. 22.0 tool (SPSS Inc., Chicago, Illinois, United States) was used to analyze all the data. The odds ratio (OR) and their 95\% confidence intervals $(95 \% \mathrm{CI})$ from multivariate logistic regression analysis were used to determine the correlations between genotypes and CC risk. A statistically significant $p$ value of $<0.05$ was considered.

\section{Results}

\section{Sociodemographic Data}

For this case control study, 392 women were included and identified as CC patients (192/48.98\%) and controls (200/ $51.02 \%$ ) according to the histopathological and clinical characteristics. The mean age of the CC patients was $49 \pm 11$ years, while control samples has a mean age of $44 \pm 9$ years. Sociodemographic characteristic samples of cases and controls are presented in - Table 1. Information regarding age, parity, educational status, ethnicity, tobacco chewing, and smoking status were compared between the CC and control groups. A higher frequency of parity was observed in women who had a parity of between 3 and $5(p=0.0003)$, were younger than 30 years old ( $p 0.00001)$, lived in rural areas ( $p$ 0.0001 ), had lower education ( $p$ 0.00001), were smokers $(p=0.001)$, and had the habit of chewing tobacco $(p=0.0001)$.

\section{Histopathological and FIGO Data}

Histopathological features with staging as per FIGO criteria and tumor size are presented in - Table 2. Keratinizing squamous cell carcinoma (KSCC) had a higher incident rate 
Table 1 Sociodemographic characteristics of cervical cancer patients and controls

\begin{tabular}{|c|c|c|c|c|c|c|c|c|}
\hline \multicolumn{3}{|c|}{ Controls, $N=200$} & \multicolumn{2}{|c|}{ Cases, $N=192$} & \multirow[t]{2}{*}{$p$-value ${ }^{a}$} & \multirow[t]{2}{*}{ OR } & \multirow[t]{2}{*}{$95 \% \mathrm{Cl}$} & \multirow[t]{2}{*}{$p$-Value } \\
\hline Age (y) & No. & $\%$ & No. & $\%$ & & & & \\
\hline $21-30$ & 6 & 3 & 10 & 5.2 & \multirow[t]{5}{*}{$<0.00001$} & 1.00 & Reference & \\
\hline $31-40$ & 62 & 31 & 32 & 16.67 & & 0.31 & $0.10-0.93$ & 0.03 \\
\hline $41-50$ & 102 & 51 & 76 & 39.59 & & 0.45 & $0.16-1.28$ & 0.12 \\
\hline $51-60$ & 16 & 8 & 44 & 22.92 & & 1.65 & $0.52-5.28$ & 0.39 \\
\hline$\geq 60$ & 30 & 15.62 & 14 & 7 & & 1.29 & $0.39-4.25$ & 0.67 \\
\hline \multicolumn{9}{|l|}{ Parity } \\
\hline$\leq 2$ & 52 & 26 & 30 & 15.62 & \multirow[t]{3}{*}{0.0003} & 1.00 & Reference & \\
\hline $3-5$ & 100 & 50 & 134 & 69.79 & & 2.32 & $1.38-3.90$ & 0.001 \\
\hline$\geq 6$ & 48 & 24 & 28 & 14.59 & & 1.01 & $0.53-1.93$ & 0.97 \\
\hline \multicolumn{9}{|c|}{ Socioeconomic status } \\
\hline Upper middle & 164 & 82 & 176 & 91.67 & \multirow[t]{2}{*}{0.004} & 1.00 & Reference & \\
\hline Lower middle & 36 & 18 & 16 & 8.33 & & 0.41 & $0.22-0.77$ & 0.004 \\
\hline \multicolumn{9}{|c|}{ Age at marriage } \\
\hline$<18$ & 84 & 42 & 64 & 33.34 & \multirow[t]{2}{*}{0.07} & 1.00 & Reference & \\
\hline $18-30$ & 116 & 58 & 128 & 66.66 & & 1.45 & $0.96-2.18$ & 0.07 \\
\hline \multicolumn{9}{|c|}{ Place of residence } \\
\hline Urban & 74 & 37 & 38 & 19.8 & \multirow[t]{2}{*}{0.0001} & 1.00 & Reference & \\
\hline Rural & 126 & 63 & 154 & 80.2 & & 2.38 & $1.51-3.76$ & 0.0001 \\
\hline \multicolumn{9}{|l|}{ Religion } \\
\hline Hindu & 96 & 48 & 146 & 76.04 & \multirow[t]{3}{*}{$<0.00001$} & 1.00 & Reference & \\
\hline Muslim & 76 & 38 & 44 & 22.91 & & 0.38 & $0.24-0.60$ & 0.0001 \\
\hline Sikh & 28 & 14 & 2 & 1.05 & & 0.05 & $0.01-0.20$ & $<0.001$ \\
\hline \multicolumn{9}{|c|}{ Educational status } \\
\hline$<5$ th & 60 & 30 & 88 & 45.84 & \multirow[t]{3}{*}{$<0.00001$} & 1.00 & Reference & \\
\hline 5th-8th & 44 & 22 & 72 & 37.5 & & 1.12 & $0.68-1.84$ & 0.66 \\
\hline$\geq 8$ th & 96 & 48 & 32 & 16.66 & & 0.23 & $0.14-0.38$ & $<0.0001$ \\
\hline \multicolumn{9}{|l|}{ Smoking status } \\
\hline No & 184 & 92 & 156 & 81.25 & \multirow[t]{2}{*}{0.001} & 1.00 & Reference & \\
\hline Yes & 16 & 8 & 36 & 18.75 & & 2.65 & $1.42-4.96$ & 0.001 \\
\hline \multicolumn{9}{|c|}{ Tobacco chewing status } \\
\hline No & 143 & 71.5 & 96 & 50 & \multirow[t]{2}{*}{0.0001} & 1.00 & Reference & \\
\hline Yes & 57 & 28.5 & 96 & 50 & & 2.51 & $1.65-3.81$ & 0.0001 \\
\hline
\end{tabular}

Note: Bolded values are significant.

${ }^{a}$ Analysis by two-sided chi-squared $\left(x^{2}\right)$ test and $p<0.05$ set as significance level (SPSS Inc., Chicago, IL, United States).

(164/85.42\%) followed by nonkeratinizing SCC (20/10.42\%) and adenocarcinoma (8/4.16\%). As per biopsy report, mild dysplasia (20/10\%) was more common, followed moderate and severe dysplasia. Stage II cancer was more common in women diagnosed with cervical carcinoma (110/57.30\%). A higher frequency was observed in women who had a 2- to 4cm tumor size (114/59.30\%).

\section{IL-10 -1082A/G Polymorphism}

IL-10-1082A/G polymorphism genotype distribution among CC patients and controls are shown in - Table 3 using the
Hardy-Weinberg equilibrium (HWE). Genotype and allele frequency distributions of SNPs among the cases and controls were significantly different $(p=0.0005)$. The HWE of both controls and CC patients was consistent $\left(\chi^{2}=2.86\right.$, $p=0.09$ and $x^{2}=11.9, p=0.0005$, respectively). The distribution of genotypes showed no deviation from HWE for both the cases and controls $\left(x^{2}=1.39, p=0.23\right.$ and $\chi^{2}=1.08$, $p=0.297$, respectively).

Overall, three genotypes (A/A, A/G, and $\mathrm{G} / \mathrm{G}$ ) and two alleles were found in this study. The control group had the following genotypes: A/A in 112 (56\%) women, A/G in 69 
Table 2 Histopathological and clinical features of cervical cancer patients

\begin{tabular}{|l|l|l|}
\hline Histopathological analysis & No. & $\%$ \\
\hline Nonkeratinizing SCC & 20 & 10.42 \\
\hline Keratinizing SCC & 164 & 85.42 \\
\hline Adenocarcinoma & 8 & 4.16 \\
\hline Dysplasia & \multicolumn{2}{|l|}{} \\
\hline Mild & 20 & 10.5 \\
\hline Moderate & 4 & 2.9 \\
\hline Severe & 0 & 0 \\
\hline FIGO staging & \multicolumn{2}{|l|}{} \\
\hline Stages I & 42 & 21.87 \\
\hline Stages II & 110 & 57.3 \\
\hline Stages III & 30 & 15.62 \\
\hline Stages IV & 10 & 5.21 \\
\hline Size of tumor & \multicolumn{2}{|l}{} \\
\hline$<2 \mathrm{~cm}$ & 38 & 19.8 \\
\hline $2-4 \mathrm{~cm}$ & 114 & 59.3 \\
\hline$>4$ cm & 34 & 17.8 \\
\hline Not specified & 6 & 3.1 \\
\hline
\end{tabular}

Abbreviations: FIGO, International Federation of Gynecology and Obstetrics; SCC, squamous cell carcinoma.

(34.5\%) women, and G/G in 19 (9.5\%) women. Among the cancer patients, 74 (38.54\%) had the A/A genotype, 107 (55.73\%) had the $A / G$ genotype, and 11 (5.73\%) had the G/G genotype. The allele frequencies were 0.73 for the $A$ allele (ancestral allele) and 0.27 for the $G$ allele (variant allele) in the controls, while among the CC patients allele frequencies were 0.66 and 0.34 for $A$ and $G$ alleles, respectively.

Genotypes and allele frequencies for statistical analysis included the dominant model and carriage rate, and are summarized in -Table 3. Frequency of the $A / G$ genotype was higher in cases as compared with controls $(p=0.0006)$. A higher frequency of $A / G+G / G$ genotype was observed in CC patients as compared with controls $(p=0.0005)$. G allele frequency was higher in CC cases $(p=0.036)$ as compared with controls. Consequently, susceptibility to $\mathrm{CC}$ was higher in women carrying the $\mathrm{A} / \mathrm{G}$ genotype (OR: 2.35; CI95\%: 1.543.58), A/G + G/G genotypes (OR: 2.03; CI95\%: 1.36-3.04), and G allele (OR: 1.39; CI95\%: 1.02-1.88). A significant association was found between the IL-10 $-1082 \mathrm{~A} / \mathrm{G}$ polymorphism and $\mathrm{CC}$.

\section{IL-10 -819C/T Polymorphism}

IL-10 -819C/T polymorphism genotype distributions among CC cases and controls are summarized in - Table 3. Overall, three genotypes $(\mathrm{C} / \mathrm{C}, \mathrm{C} / \mathrm{T}$, and $\mathrm{T} / \mathrm{T})$ and two alleles ( $\mathrm{C}$ and $\mathrm{T}$ ) were observed in this study. Genotypes frequencies were 63 (31\%) for C/C, 91 (45.50\%) for C/T, and 46 (23\%) for T/T in the control group, and 61 (31.77\%) for C/C, 88 (45.84\%) for C/T, and 43 (22.39\%) for T/T, respectively, in CC patients. The allele frequencies were 0.54 for allele $C$ (ancestral allele) and 0.46 for T allele (variant allele) in the controls and 0.54 and 0.46 for alleles $\mathrm{C}$ and $\mathrm{T}$, respectively, among the CC patients. No significant association was found when compared with the controls $(p>0.05)$.

An association between IL-10 -1082A/G gene polymorphism in tobacco chewers along with smokers, summarized in - Table 4. In comparison to the controls, there was no association was found among genotype and allele frequencies between tobacco chewers and smokers $(p>0.05)$. IL-10 $-819 \mathrm{C} / \mathrm{T}$ gene polymorphism analysis revealed that no significant association was found in tobacco chewers and smokers when compared with the controls ( $\mathrm{p}>0.05$ ).

For histological grade, all 192 patients were included because they had the histological classification on the basis of the biopsy report. Considering the influence of IL-10 1082 $\mathrm{A} / \mathrm{G}$ polymorphism on lesion development, the dominant model was adopted to make a better distribution among genotypes and significant association $(p=0.0003)$ was observed (-Table 5) while statistical analysis of IL-10 819 C/T polymorphism revealed no significant association between genotype and allele distribution, as shown in - Table 5.

There was a significant association between IL-10 $1082 \mathrm{~A} /$ $\mathrm{G}$ polymorphism genotypes and clinical staging of $\mathrm{CC}$ patients categorized as per the FIGO criteria $(p=0.0006$, 0.0009 , and 0.27 ) as summarized in - Table 6. No association was observed between IL-10 819 C/T genotypes and clinical staging of CC patients (-Table 6 ).

\section{Discussion}

CC has been associated with a significantly increased rate of cancer-related mortality among women in underdeveloped nations. ${ }^{31}$ CC develops and progresses as a result of several factors. Surprisingly, a prominent fundamental cause of cervix malignancies is the host genetic component or genetic variation. ${ }^{32}$ Furthermore, it has been established that cytokine production varies widely among individuals and that these disparities may be determined by genetics. Extensive genome-wide association studies (GWAS) or genetic association studies have been conducted to determine the genetic variables that make a woman vulnerable to developing this carcinogenicity. ${ }^{33-35}$ At least 50 polymorphic loci have been identified thus far, including -2849, -2776, -2769, and -2763 to date. ${ }^{36}$ IL-10 -1082A/G (rs1800870), -819T/C (rs1800871), and $-592 \mathrm{C} / \mathrm{A}$ (rs1800872) are the three most prevalent SNPs in the promoter region that have been demonstrated to have a substantial impact on gene transcription and expression. ${ }^{37}$ According to certain genetic study, these polymorphisms potentially enhance and/or change an individual's susceptibility to many cancers, especially head and neck cancer, gastric cancer, leukemia, and others. ${ }^{38-40}$ Our research looked into whether the IL-10 rs1800870 (-1082A/G) and rs1800871 (-819C/T) polymorphisms are relevant to CC, and we established an association between them.

The correlation between numerous genetic variants in distinct cytokine genes has been evaluated, and it was 
Table 3 Distribution and association analysis of IL-10 genotypes among cervical cancer cases healthy controls

\begin{tabular}{|c|c|c|c|c|c|c|c|c|c|c|c|}
\hline \multirow{3}{*}{$\begin{array}{l}\text { IL-10 } 1082 \mathrm{~A} / \mathrm{G} \\
\text { Genotype }\end{array}$} & \multicolumn{6}{|c|}{ Genotype frequencies } & \multicolumn{5}{|c|}{ Association analysis } \\
\hline & \multicolumn{2}{|l|}{ Controls } & \multirow{2}{*}{$\frac{\text { HWE }}{x^{2}}$} & \multirow[b]{2}{*}{$p$-value } & \multicolumn{2}{|l|}{ Cases } & \multirow{2}{*}{$\begin{array}{l}\text { HWE } \\
x^{2}\end{array}$} & \multirow[b]{2}{*}{$p$-value } & \multicolumn{3}{|c|}{ Cases vs. controls } \\
\hline & $N=200$ & (\%) & & & $N=192$ & (\%) & & & OR & $95 \% \mathrm{Cl}$ & $p$-value \\
\hline $\mathrm{AA}$ & 112 & 56 & & & 74 & 38.54 & & & 1 & Reference & \\
\hline AG & 69 & 34.5 & 2.86 & 0.09 & 107 & 55.73 & 11.91 & 0.0005 & 2.35 & $1.54-3.58$ & 0.0006 \\
\hline GG & 19 & 9.5 & & & 11 & 5.73 & & & 0.88 & $0.39-1.95$ & 0.74 \\
\hline$A G+G G$ & 88 & 44 & & & 118 & 61.46 & & & 2.03 & $1.36-3.04$ & 0.0005 \\
\hline \multicolumn{12}{|l|}{ Allele } \\
\hline A & 293 & 73.25 & & & 255 & 66.4 & & & 1 & Reference & \\
\hline G & 107 & 26.75 & & & 129 & 33.6 & & & 1.39 & $1.02-1.88$ & 0.036 \\
\hline \multicolumn{12}{|l|}{ Carriage rate } \\
\hline $\mathrm{A}(+)$ & 181 & 90.5 & & & 181 & 94.27 & & & 1 & Reference & \\
\hline A (-) & 19 & 9.5 & & & 11 & 5.73 & & & 0.58 & $0.27-1.25$ & 0.16 \\
\hline$G(+)$ & 88 & 44 & & & 118 & 61.46 & & & 1 & Reference & \\
\hline G (-) & 112 & 56 & & & 74 & 38.54 & & & 0.49 & $0.33-0.74$ & 0.005 \\
\hline \multicolumn{12}{|c|}{ IL-10 819 C/T genotype } \\
\hline CC & 63 & 31.5 & & & 61 & 31.77 & & & 1 & Reference & \\
\hline $\mathrm{CT}$ & 91 & 45.5 & 1.39 & 0.23 & 88 & 45.84 & 1.08 & 0.297 & 1 & $0.63-1.58$ & 0.99 \\
\hline TT & 46 & 23 & & & 43 & 22.39 & & & 0.97 & $0.56-1.66$ & 0.89 \\
\hline $\mathrm{CT}+\mathrm{TT}$ & 137 & 68.5 & & & 131 & 68.23 & & & 0.99 & $0.65-1.51$ & 0.95 \\
\hline \multicolumn{12}{|l|}{ Allele } \\
\hline C & 217 & 54.25 & & & 210 & 54.69 & & & 1 & Reference & \\
\hline$T$ & 183 & 45.75 & & & 174 & 45.31 & & & 0.98 & $0.74-1.30$ & 0.9 \\
\hline \multicolumn{12}{|l|}{ Carriage rate } \\
\hline$C(+)$ & 154 & 77 & & & 149 & 77.6 & & & 1 & Reference & \\
\hline C (-) & 46 & 23 & & & 43 & 22.4 & & & 0.97 & $0.60-1.55$ & 0.88 \\
\hline$T(+)$ & 137 & 68.5 & & & 131 & 68.23 & & & 1 & Reference & \\
\hline$T(-)$ & 63 & 31.5 & & & 61 & 31.77 & & & 1.01 & $0.66-1.55$ & 0.95 \\
\hline
\end{tabular}

Abbreviation: HWE, Hardy-Weinberg equilibrium.

observed that these polymorphisms enhance the risk of CC. Inflammatory mediators seem to be crucial signaling molecules produced by various cells in the human body. They are connected to the innate immunity, which plays a significant role in establishing the immunological response to cancers and viral infections. ${ }^{41,42}$ As a consequence, genetic variations in cytokine-related coding genes may have the potential to cause cancer by altering their function or creating an excessive number of cytokines. ${ }^{43-45}$

IL-10 is a major anti-inflammatory cytokine with antiangiogenic and immunosuppressive characteristics. Genetic variants in the IL-10 gene have been found to affect cytokine levels reported by various studies. As a consequence, IL-10 could have both tumor-protective and tumor-promoting properties. ${ }^{46,47}$ Multiple studies have looked at both enhancement and deterioration in levels of IL-10 in CC. ${ }^{48} \mathrm{~A}$ case control study published by Stanczuk et al revealed that IL-10 -1082A/G gene polymorphism was significantly associated with increased risk of CC and their findings suggested that women carrying the $A / G$ genotype were associated with higher risk of CC in the African population. ${ }^{49}$ According to Singhal et al, the A/G genotypes may considerably enhance the risk of CC development when compared with the AA genotype in the IL-10 -1082A/G polymorphism. ${ }^{24}$ Our current study shows that IL-10 rs1800870 (-1082A/G) polymorphism is associated with increased CC susceptibility. In this study, women carrying $\mathrm{A} / \mathrm{G}$ and $\mathrm{A} / \mathrm{G}+\mathrm{G} / \mathrm{G}$ genotypes showed 2.35-fold and 2.03 times significantly higher risk ( $p=0.0006$ and 0.0005$)$ and women with $\mathrm{G}$ allele were also significantly associated with increased risk of CC $(p=0.036)$ as compared with controls. The findings of our study are in accordance with those of various previous ethnic studies. IL$10-1082 \mathrm{G}$ allele was significantly associated with the development of CC among Zimbabwean population as compared with the IL-1082A allele. ${ }^{24}$ Matsumoto et al also established an association between IL-10 -1082G allele and CC susceptibility as compared with the IL-1082A allele among Japanese women. ${ }^{28}$ According to Chagas et al, the IL-10 -1082 


\begin{tabular}{|c|c|c|c|c|c|c|c|c|c|c|c|c|c|c|c|c|c|c|c|c|c|c|c|c|c|c|}
\hline \multirow{3}{*}{ 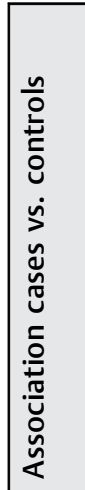 } & 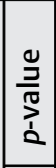 & 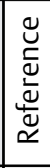 & 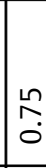 & $\frac{\pi}{\mathfrak{O}}$ & $\overline{0}$ & & 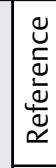 & ơ & & 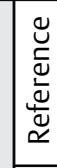 & $\begin{array}{l} \\
\text { م } \\
0 \\
0\end{array}$ & : & ז & & 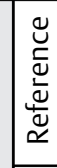 & $\begin{array}{l} \\
\infty \\
1 \\
0 \\
0\end{array}$ & 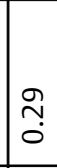 & 令 & & 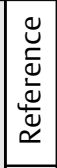 & $\begin{array}{l}\stackrel{m}{n}_{0} \\
0\end{array}$ & & 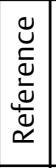 & $\mid \begin{array}{c} \\
0 \\
0\end{array}$ & 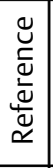 & مै \\
\hline & $\begin{array}{l}\text { च } \\
\text { ڤેํ }\end{array}$ & 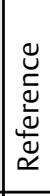 & $\mid \begin{array}{c}\mathfrak{N} \\
\stackrel{+}{f} \\
b \\
0 \\
0 \\
0\end{array}$ & $\left\{\begin{array}{l}\infty \\
6 \\
\vdots \\
m \\
0 \\
0\end{array}\right.$ & 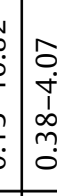 & & 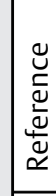 & $\begin{array}{l}8 \\
\text { mi } \\
1 \\
\text { f } \\
0\end{array}$ & & 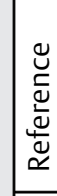 & \begin{tabular}{l}
$\bar{n}$ \\
$\dot{\sim}$ \\
$\overline{1}$ \\
$m$ \\
\hdashline \\
0
\end{tabular} & : & 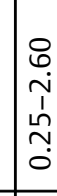 & & 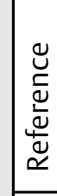 & 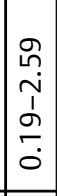 & 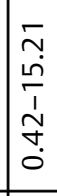 & $\mid \begin{array}{c}0 \\
\stackrel{n}{n} \\
m \\
1 \\
m \\
\tilde{o} \\
\end{array}$ & & 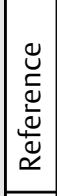 & $\begin{array}{l}0 \\
\text { ஸn } \\
m \\
1 \\
\dot{0} \\
0 \\
0\end{array}$ & & 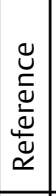 & $\mid \begin{array}{c}\tilde{\alpha} \\
\text { மn } \\
\tilde{1} \\
0 \\
6 \\
0 \\
0\end{array}$ & 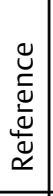 & 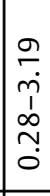 \\
\hline & 。ั & - & $\underset{ָ}{\stackrel{\Gamma}{n}}$ & $\stackrel{\text { ㄴ }}{-}$ & 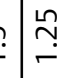 & & - & $\stackrel{\sim}{r}$ & & - & 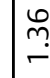 & - & $\begin{array}{l}\infty \\
0\end{array}$ & & - & $\begin{array}{l}0 \\
0 \\
0\end{array}$ & 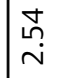 & 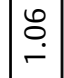 & & - & $\underset{+}{\stackrel{g}{+}}$ & & - & $\left|\begin{array}{l}\infty \\
0 \\
\dot{m}\end{array}\right|$ & - & 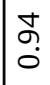 \\
\hline \multirow{4}{*}{ 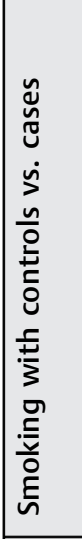 } & ๑ & $\begin{array}{l}\stackrel{n}{f} \\
\dot{f} \\
\dot{f}\end{array}$ & $\underset{\sim}{\tilde{\sigma}}$ & $\begin{array}{l}m \\
\infty \\
\infty\end{array}$ & 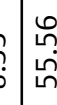 & & $\mid \begin{array}{l}n \\
0 \\
\infty \\
0\end{array}$ & $\begin{array}{l}\stackrel{n}{\alpha} \\
\frac{m}{m}\end{array}$ & & $\begin{array}{l}\hat{b} \\
\bar{\sigma}\end{array}$ & $\underset{m}{m} \underset{\infty}{\infty}$ & 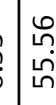 & $\underset{\mathscr{f}}{\stackrel{f}{f}}$ & & $\begin{array}{l}\mp \\
\dot{\omega} \\
m\end{array}$ & $\begin{array}{l}\tilde{v} \\
m \\
m \\
m\end{array}$ & $\begin{array}{l}\stackrel{n}{\mu 口} \\
m \\
m\end{array}$ & $\mid \begin{array}{l}0 \\
\infty \\
\hat{\omega} \\
\end{array}$ & & $\begin{array}{l}\infty \\
\stackrel{\infty}{\hat{N}} \\
\text { ஸे }\end{array}$ & $\underset{\stackrel{N}{*}}{\stackrel{\sim}{*}}$ & & $\begin{array}{l}\qquad \\
\dot{\sigma} \\
\dot{0}\end{array}$ & $\mid \begin{array}{c}\stackrel{\sim}{n} \\
m \\
m\end{array}$ & $\begin{array}{l}0 \\
\infty \\
\tilde{b}\end{array}$ & 富 \\
\hline & - & 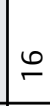 & 등 & $m$ & , & & g & $\stackrel{\Re}{\sim}$ & & $\stackrel{m}{m}$ & $\mathrm{~m}$ & i & 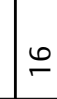 & & $\stackrel{m}{ }$ & $\simeq$ & $=$ & $\tilde{\sim}$ & & $\stackrel{\infty}{m}$ & $\stackrel{+}{m}$ & & $\stackrel{\llcorner}{\sim}$ & $\mp$ & $\cong$ & $\stackrel{m}{r}$ \\
\hline & ঠ̊ & i 묘 & 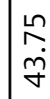 & 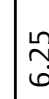 & $\begin{array}{l}y \\
\vdots\end{array}$ & & $\begin{array}{l}\frac{1}{\infty} \\
\bar{r}\end{array}$ & $\begin{array}{l}\stackrel{m}{c} \\
\infty \\
\sim\end{array}$ & & $\begin{array}{l}\frac{n}{n} \\
\tilde{m}\end{array}$ & $\stackrel{\Perp}{\tilde{n}}$ & 옹 & 음 & & $\stackrel{\stackrel{\sim}{n}}{\stackrel{m}{m}}$ & in & $\stackrel{\stackrel{\sim}{\sim}}{\stackrel{\longrightarrow}{\sim}}$ & $\stackrel{n}{\tilde{\omega}}$ & & $\begin{array}{l}n \\
\sim \\
\sigma\end{array}$ & $\stackrel{\stackrel{n}{n}}{\stackrel{n}{m}}$ & & \begin{tabular}{|l}
$\stackrel{\llcorner}{r}$ \\
$\stackrel{\infty}{\infty}$
\end{tabular} & $\stackrel{\stackrel{n}{\sim}}{\stackrel{\sim}{\sim}}$ & 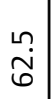 & $\stackrel{\substack{n \\
m}}{m}$ \\
\hline & & $\infty$ & $r$ & - & $-\infty$ & & $\stackrel{\sim}{\sim}$ & a & & $\stackrel{\llcorner}{\sim}$ & - & $\infty$ & $\infty$ & & 0 & $\infty$ & $\sim$ & $\circ$ & & $\stackrel{\curvearrowright}{\sim}$ & $\stackrel{\simeq}{\simeq}$ & & \pm & $\sim$ & $\stackrel{\circ}{-}$ & 6 \\
\hline \multirow{3}{*}{ 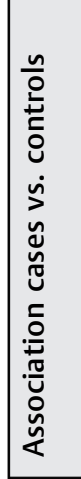 } & 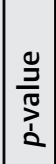 & 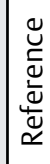 & $\stackrel{\text { nn }}{\stackrel{0}{0}}$ & à & $=0$ & & 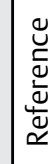 & ำ & & 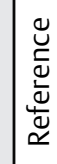 & 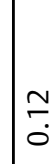 & : & م̊ & & 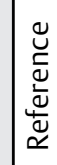 & $\hat{0}$ & $\hat{o}$ & $\begin{array}{l}n \\
0 \\
0\end{array}$ & & 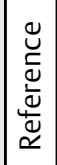 & \begin{tabular}{|l} 
\\
0 \\
0 \\
0
\end{tabular} & & 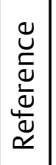 & $\begin{array}{l}\infty \\
0 \\
0\end{array}$ & 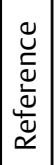 & 兄 \\
\hline & 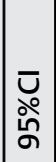 & 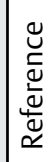 & 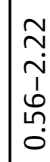 & 告 & 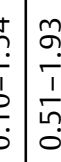 & & 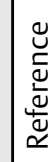 & 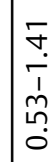 & & 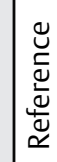 & $\begin{array}{c}\hat{m} \\
\\
0 \\
\\
\end{array}$ & : & 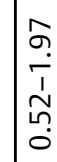 & & 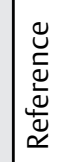 & $\begin{array}{c}\bar{\gamma} \\
\sim \\
1 \\
\Lambda \\
น \\
0 \\
0\end{array}$ & 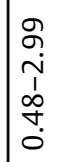 & 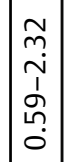 & & 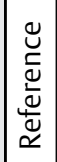 & $\begin{array}{l}\hat{N} \\
\overline{1} \\
1 \\
\sigma \\
\omega \\
0 \\
0\end{array}$ & & 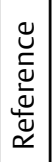 & 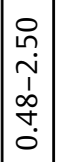 & 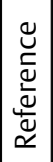 & 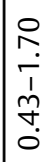 \\
\hline & ơ & - & $\stackrel{\sim}{\check{r}}$ & 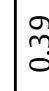 & & & - & $\mid \begin{array}{l}\mathscr{0} \\
0 \\
0\end{array}$ & & - & $\stackrel{\hat{m}}{0}$ & - & & & - & $\stackrel{0}{\check{r}}$ & $\stackrel{g}{\rightleftarrows}$ & 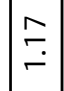 & & - & 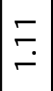 & & - & 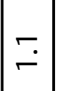 & - & $\begin{array}{l}\mathscr{0} \\
0 \\
0\end{array}$ \\
\hline \multirow{4}{*}{ 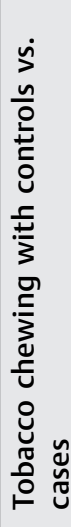 } & $\overparen{Ð}$ & $\begin{array}{l}\tilde{O} \\
\dot{\sigma} \\
\dot{q}\end{array}$ & $\begin{array}{l}\bar{n} \\
\text { กิ }\end{array}$ & 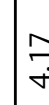 & 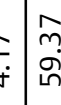 & & 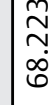 & $\begin{array}{l}\hat{N} \\
\bar{m} \\
\text {. }\end{array}$ & & $\begin{array}{l} \pm \\
\infty \\
\text { ம் }\end{array}$ & 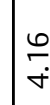 & 命 & $\begin{array}{l}n \\
\stackrel{f}{q}\end{array}$ & & 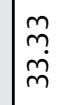 & 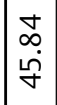 & $\begin{array}{l}m \\
\infty \\
\grave{N} \\
\end{array}$ & $\begin{array}{l}\hat{b} \\
\dot{b} \\
\dot{0}\end{array}$ & & $\begin{array}{l}\stackrel{n}{N} \\
\stackrel{L}{n} \\
\llcorner\end{array}$ & $\begin{array}{l}\stackrel{n}{\hat{m}} \\
\dot{v}\end{array}$ & & $\begin{array}{l}\tilde{c} \\
\bar{r} \\
\bar{r}\end{array}$ & 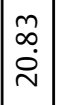 & $\mid \begin{array}{l}\hat{6} \\
\dot{0}\end{array}$ & $\begin{array}{l}m \\
m \\
m\end{array}$ \\
\hline & $z$ & $\stackrel{m}{m}$ & ติ & $\nabla$ & in & & $\bar{m}$ & $\overline{6}$ & & $\alpha$ & $\nabla$ & in & ले & & $\tilde{m}$ & 守 & ㄱ. & ర్ & & $\stackrel{\infty}{\circ}$ & $\varpi_{\infty}$ & & $\stackrel{0}{2}$ & থ & ఫ & $\tilde{m}$ \\
\hline & ๖̊ & 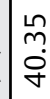 & $\underset{m}{\stackrel{m}{g}}$ & กิ & 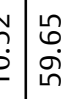 & & $\begin{array}{l}\bar{\sigma} \\
\dot{\sigma}\end{array}$ & $\begin{array}{l}\text { ò } \\
\text { ம் }\end{array}$ & & $\begin{array}{l}f \\
\curvearrowright \\
\infty\end{array}$ & 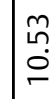 & $\begin{array}{l}n \\
6 \\
0 \\
n\end{array}$ & $\begin{array}{l}\stackrel{n}{n} \\
\tilde{q} \\
o\end{array}$ & & $\begin{array}{l}\mathbf{\infty} \\
\infty \\
\dot{\omega} \\
m\end{array}$ & $\begin{array}{l}0 \\
\infty \\
\dot{\gamma} \\
\dot{\gamma}\end{array}$ & $\underline{m}$ & $\mid \begin{array}{l}0 \\
\tilde{\rho} \\
\end{array}$ & & $\mid \begin{array}{l}\hat{n} \\
\infty \\
\infty\end{array}$ & $\underset{\stackrel{n}{\sim}}{\tilde{\gamma}}$ & & $\begin{array}{l}\hat{0} \\
\dot{\infty}\end{array}$ & $\begin{array}{l}m \\
\sigma \\
\sigma\end{array}$ & $\mid \begin{array}{l}\frac{0}{\tilde{\theta}} \\
\hat{\sigma}\end{array}$ & $\begin{array}{l} \\
\infty \\
\omega \\
\dot{m}\end{array}$ \\
\hline & $\mid \begin{array}{l}10 \\
11 \\
z\end{array}$ & $\stackrel{\sim}{\sim}$ & $\stackrel{\infty}{\sim}$ & 0 & $\stackrel{+}{m}$ & & I & f & & in & o & $\stackrel{m}{m}$ & $\cong$ & & $\bar{N}$ & $\stackrel{\stackrel{\Omega}{\sim}}{\sim}$ & $\mp$ & m & & 6 & f & & $\mathscr{f}$ & $\mp$ & $\stackrel{\varphi}{m}$ & $\bar{\sim}$ \\
\hline 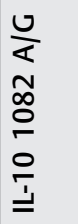 & 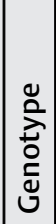 & |\& & 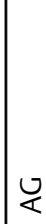 & & $\begin{array}{l}\text { U } \\
+ \\
\text { U. }\end{array}$ & 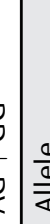 & 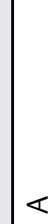 & & $\frac{\pi}{5}$ & $\underset{\leftarrow}{\overparen{E}}$ & $\frac{I}{4}$ & $=\underbrace{}_{\cup}$ & I & 5 & 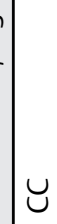 & 七 & $\vDash$ & $\begin{array}{l}E \\
+ \\
\longleftarrow\end{array}$ & $\frac{\frac{\partial}{\omega}}{\frac{\partial}{\alpha}}$ & $u$ & & & $\begin{array}{l}Ð \\
\cup\end{array}$ & $\begin{array}{l}I \\
\cup\end{array}$ & & $I$ \\
\hline
\end{tabular}




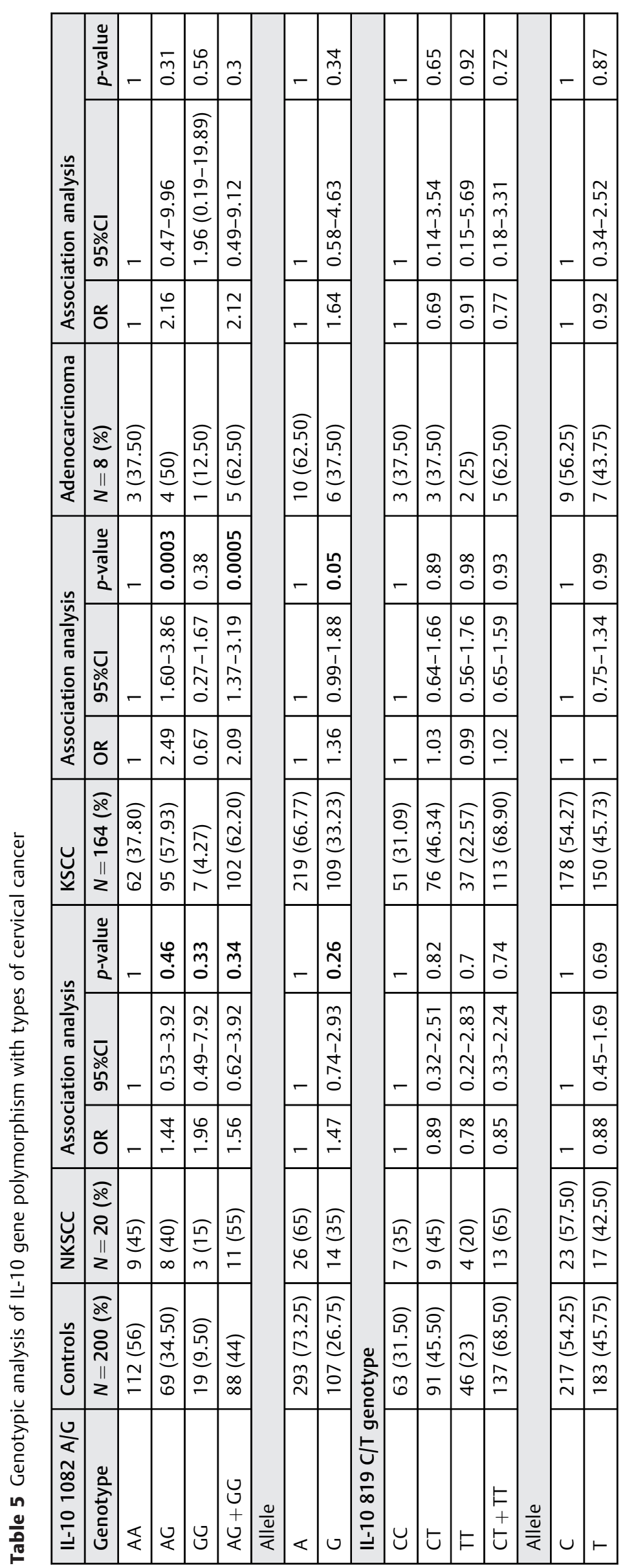


Table 6 Association analysis of SNPs (-1082A/G and -819C/T) in the promoter region of IL-10 gene with clinical stage of cervical cancer cases

\begin{tabular}{|c|c|c|c|c|c|c|c|c|c|c|c|c|}
\hline \multirow{2}{*}{$\begin{array}{l}\text { IL-10 } \\
1082 \text { A/G } \\
\text { Genotype }\end{array}$} & \multicolumn{2}{|l|}{ Controls } & \multicolumn{2}{|c|}{$\begin{array}{l}\text { CC with I+ } \\
\text { II }\end{array}$} & \multirow[t]{2}{*}{ OR } & \multirow[t]{2}{*}{$95 \% \mathrm{Cl}$} & \multirow[t]{2}{*}{$p$-value } & \multicolumn{2}{|c|}{$\begin{array}{l}\text { CC with } \\
\text { III + IV }\end{array}$} & \multirow[t]{2}{*}{ OR } & \multirow[t]{2}{*}{$95 \% \mathrm{Cl}$} & \multirow[t]{2}{*}{$p$-value } \\
\hline & $N=200$ & (\%) & $N$ & (\%) & & & & $N$ & $(\%)$ & & & \\
\hline $\mathrm{AA}$ & 112 & 56 & 58 & 38.16 & 1.00 & Reference & Reference & 16 & 40 & 1.00 & Reference & Reference \\
\hline AG & 69 & 34.5 & 88 & 57.89 & 2.5 & $1.57-3.85$ & 0.0006 & 19 & 47.5 & 1.9 & $0.93-4.00$ & 0.07 \\
\hline GG & 19 & 9.5 & 6 & 3.95 & 0.6 & $0.23-1.61$ & 0.31 & 5 & 12.5 & 1.8 & $0.60-5.62$ & 0.27 \\
\hline$A G+G G$ & 88 & 44 & 94 & 61.84 & 2.1 & $1.34-3.17$ & 0.0009 & 24 & 60 & 1.9 & $0.96-3.81$ & 0.06 \\
\hline \multicolumn{13}{|l|}{ Allele } \\
\hline A & 293 & 73.3 & 204 & 67.1 & 1.00 & Reference & Reference & 51 & 63.8 & 1.00 & Reference & Reference \\
\hline G & 107 & 26.8 & 100 & 32.9 & 1.3 & $0.97-1.86$ & 0.076 & 29 & 36.3 & 1.6 & $0.94-2.58$ & 0.08 \\
\hline \multicolumn{13}{|c|}{ IL-10 819 C/T genotype } \\
\hline CC & 63 & 31.5 & 49 & 32.24 & 1.00 & Reference & Reference & 12 & 30 & 1.00 & Reference & Reference \\
\hline CT & 91 & 45.5 & 73 & 48.03 & 1.03 & $0.64-1.67$ & 0.9 & 15 & 37.5 & 0.87 & $0.38-1.97$ & 0.73 \\
\hline TT & 46 & 23 & 30 & 19.73 & 0.84 & $0.46-1.52$ & 0.55 & 13 & 32.5 & 1.48 & $0.62-3.55$ & 0.37 \\
\hline $\mathrm{CT}+\mathrm{TT}$ & 137 & 68.5 & 103 & 67.76 & 0.97 & $0.61-1.52$ & 0.88 & 28 & 70 & 1.07 & $0.51-2.25$ & 0.85 \\
\hline \multicolumn{13}{|l|}{ Allele } \\
\hline C & 217 & 54.3 & 171 & 56.25 & 1.00 & Reference & Reference & 39 & 48.8 & 1.00 & Reference & Reference \\
\hline $\mathrm{T}$ & 183 & 45.8 & 133 & 43.75 & 0.92 & $0.68-1.25$ & 0.59 & 41 & 51.3 & 1.25 & $0.77-2.02$ & 0.36 \\
\hline
\end{tabular}

variation locus may play a imperative role in the progression and development of CC in the Brazilian population. ${ }^{27}$ Our study demonstrated that women carrying the A/G genotype have higher risk of $\mathrm{CC}$, followed by those carrying the $\mathrm{G} / \mathrm{G}$ genotype as compared with those carrying the $\mathrm{A} / \mathrm{A}$ genotype among nonkeratinizing SCC and controls summarized in - Table $5(p=0.46)$. In the context of KSCC, there was a higher incident of $A / G$ and $A / G+G / G$ compared with the $A / A$ genotype ( $p=0.0003$ and 0.0005 ), while no association was found between adenocarcinoma and IL-10 1082A/G polymorphism. In this study, there was no significant association between IL-10 -819C/T polymorphism and CC with subgroup analysis as compared with controls. A significant association was found between the IL-10 $1082 \mathrm{~A} / \mathrm{G}$ genotype and the clinical stage of CC ( $p=0.0006$ and 0.0009$)$ compared with the controls (-Table 6).

\section{Conclusion}

The finding of our study revealed significant association of IL$101082 \mathrm{~A} / \mathrm{G}$ polymorphism with CC susceptibility. Women carrying $A / G$ and $A / G+G / G$ genotypes have an increased risk of $\mathrm{CC}$, suggesting an association with the presence of $\mathrm{G}$ allele, confirmed by allele analysis. Furthermore, due to the high prevalence and mortality of $\mathrm{CC}$, our results highlighted the need to extend prevention efforts regarding the disease's significance and urge gynecological follow-ups. The development of a susceptibility framework comprising individual characteristics that increase the risk of CC development, as well as genetic biomarkers such as the IL-10 -1082A/G polymorphism, could be a potential method for assessing the risk of CC. Elevation of serum level is also associated with increased risk of CC compared with controls.

\section{Funding}

This study was financially supported by the Department of Biotechnology, Ministry of Science and Technology, New Delhi, Government of India (sanction number: 6242-P110/RGCB/PMD/DBT/SHKR/2015).

\section{Conflict of Interest}

None declared.

\section{Acknowledgments}

We acknowledge and appreciate our colleagues Mr. Mark Rector Charles for their valuable suggestions and Mr. Ale Eba and Mr. Muneshwar Rajput for technical assistance in this study.

\section{References}

1 Bray F, Ferlay J, Soerjomataram I, Siegel RL, Torre LA, Jemal A. Global cancer statistics 2018: GLOBOCAN estimates of incidence and mortality worldwide for 36 cancers in 185 countries. CA Cancer J Clin 2018;68(06):394-424

2 Sadri Nahand J, Moghoofei M, Salmaninejad A, et al. Pathogenic role of exosomes and microRNAs in HPV-mediated inflammation and cervical cancer: a review. Int J Cancer 2020;146(02):305-320

3 Ghasemi F, Shafiee M, Banikazemi Z, et al. Curcumin inhibits NF$\mathrm{kB}$ and $\mathrm{Wnt} / \beta$-catenin pathways in cervical cancer cells. Pathol Res Pract 2019;215(10):152556

4 Nahand JS, Taghizadeh-Boroujeni S, Karimzadeh M, et al. microRNAs: new prognostic, diagnostic, and therapeutic biomarkers in cervical cancer. J Cell Physiol 2019;234(10):17064-17099 
5 Torre LA, Bray F, Siegel RL, Ferlay J, Lortet-Tieulent J, Jemal A. Global cancer statistics, 2012. CA Cancer J Clin 2015;65(02): 87-108

6 Cohen PA, Jhingran A, Oaknin A, Denny L. Cervical cancer. Lancet 2019;393(10167):169-182

7 Pratap P, Raza ST, Zaidi G, Charles MR, Kunwar S. Molecular biology of human papillomavirus, cervical carcinoma and its management. Canadian J Clin Nutr 2021;9(01):71-88

8 Chen X, Jiang J, Shen H, Hu Z. Genetic susceptibility of cervical cancer. J Biomed Res 2011;25(03):155-164

9 Kessler TA. Cervical cancer: prevention and early detection. Semin Oncol Nurs 2017;33(02):172-183

10 Kjellberg L, Hallmans G, Ahren AM, et al. Smoking, diet, pregnancy and oral contraceptive use as risk factors for cervical intraepithelial neoplasia in relation to human papillomavirus infection. Br J Cancer 2000;82(07):1332-1338

11 Martínez-Nava GA, Fernández-Niño JA, Madrid-Marina V, TorresPoveda K. Cervical cancer genetic susceptibility: a systematic review and meta-analyses of recent evidence. PLoS One 2016;11 (07):e0157344

12 Magnusson PK, Lichtenstein P, Gyllensten UB. Heritability of cervical tumours. Int J Cancer 2000;88(05):698-701

13 Mehta AM, Mooij M, Branković I, Ouburg S, Morré SA, Jordanova ES. Cervical carcinogenesis and immune response gene polymorphisms: a review. J Immunol Res 2017;2017:8913860

14 zur Hausen H. Papillomaviruses and cancer: from basic studies to clinical application. Nat Rev Cancer 2002;2(05):342-350

15 Sasagawa T, Takagi H, Makinoda S. Immune responses against human papillomavirus (HPV) infection and evasion of host defense in cervical cancer. J Infect Chemother 2012;18(06):807-815

16 Gao J, Wei L, Fu R, et al. Association of Interleukin-10 polymorphisms (rs1800872, rs1800871, and rs1800896) with Predisposition to IgA nephropathy in a Chinese Han population: a casecontrol study. Kidney Blood Press Res 2017;42(01):89-98

17 Ding $\mathrm{Q}$ Shi Y, Fan B, et al. The interleukin-10 promoter polymorphism rs1800872 $(-592 \mathrm{C}>\mathrm{A})$, contributes to cancer susceptibility: meta-analysis of 16,785 cases and 19,713 controls. PLoS One 2013;8(02):e57246

18 Dai ZJ, Wang XJ, Zhao Y, et al. Effects of interleukin-10 polymorphisms (rs1800896, rs1800871, and rs1800872) on breast cancer risk: evidence from an updated meta-analysis. Genet Test Mol Biomarkers 2014;18(06):439-445

19 Mohammadi S, Saghaeian Jazi M, Zare Ebrahimabad M, et al. Interleukin 10 gene promoter polymorphisms (rs1800896, rs1800871 and rs1800872) and haplotypes are associated with the activity of systemic lupus erythematosus and IL10 levels in an Iranian population. Int J Immunogenet 2019;46(01):20-30

20 Holster A, Nuolivirta K, Törmänen S, et al. Interleukin-10 gene polymorphism rs1800896 is associated with post-bronchiolitis asthma at 11-13 years of age. Acta Paediatr 2019;108(11):2064-2069

21 Du GH, Wang JK, Richards JR, Wang JJ. Genetic polymorphisms in tumor necrosis factor alpha and interleukin-10 are associated with an increased risk of cervical cancer. Int Immunopharmacol 2019;66:154-161

22 Bai CY, Shi XY, He J, Xue J, Feng Y. Association between IL-10 genetic variations and cervical cancer susceptibility in a Chinese population. Genet Mol Res 2016;15(03):

$23 \mathrm{Ni} \mathrm{J}$, Ye Y, Teng $\mathrm{F}, \mathrm{Wu}$ Q. Interleukin 10 polymorphisms and cervical cancer risk: a meta-analysis. Int J Gynecol Cancer 2013;23 (01):126-133

24 Singhal P, Kumar A, Bharadwaj S, Hussain S, Bharadwaj M. Association of IL-10 GTC haplotype with serum level and HPV infection in the development of cervical carcinoma. Tumour Biol 2015;36(04):2287-2298

25 Torres-Poveda K, Burguete-García AI, Cruz M, et al. The SNP at -592 of human IL-10 gene is associated with serum IL-10 levels and increased risk for human papillomavirus cervical lesion development. Infect Agent Cancer 2012;7(01):32
26 Zoodsma M, Nolte IM, Schipper M, et al. Interleukin-10 and Fas polymorphisms and susceptibility for (pre)neoplastic cervical disease. Int J Gynecol Cancer 2005;15(Suppl 3):282-290

27 Chagas BS, Gurgel AP, da Cruz HL, et al. An interleukin-10 gene polymorphism associated with the development of cervical lesions in women infected with Human Papillomavirus and using oral contraceptives. Infect Genet Evol 2013; 19:32-37

28 Matsumoto K, Oki A, Satoh T, et al. Interleukin-10 -1082 gene polymorphism and susceptibility to cervical cancer among Japanese women. Jpn J Clin Oncol 2010;40(11):1113-1116

29 Huang T, Shu Y, Cai YD. Genetic differences among ethnic groups. BMC Genomics 2015;16:1093

30 Sreeja L, Syamala V, Raveendran PB, Santhi S, Madhavan J, Ankathil R. p53 Arg72Pro polymorphism predicts survival outcome in lung cancer patients in Indian population. Cancer Invest 2008;26(01):41-46

31 Zhang L, Jiang Y, Lu X, et al. Genomic characterization of cervical cancer based on human papillomavirus status. Gynecol Oncol 2019;152(03):629-637

32 Bahrami A, Hasanzadeh M, Shahidsales S, et al. Genetic susceptibility in cervical cancer: from bench to bedside. J Cell Physiol 2018;233(03):1929-1939

33 Shafabakhsh R, Reiter RJ, Mirzaei H, Teymoordash SN, Asemi Z. Melatonin: a new inhibitor agent for cervical cancer treatment. J Cell Physiol 2019;234(12):21670-21682

34 Fernandes AP, Gonçalves MA, Simões RT, Mendes-Junior CT, Duarte G, Donadi EA. A pilot case-control association study of cytokine polymorphisms in Brazilian women presenting with HPV-related cervical lesions. Eur J Obstet Gynecol Reprod Biol 2008;140(02):241-244

35 Sharma A, Rajappa M, Saxena A, Sharma M. Cytokine profile in Indian women with cervical intraepithelial neoplasia and cancer cervix. Int J Gynecol Cancer 2007;17(04):879-885

36 Willeke P, Gaubitz M, Schotte H, Becker H, Domschke W, Schlüter B. The role of interleukin-10 promoter polymorphisms in primary Sjogren's syndrome. Scand J Rheumatol 2008;37(04): 293-299

37 Ouma C, Davenport GC, Were T, et al. Haplotypes of IL-10 promoter variants are associated with susceptibility to severe malarial anemia and functional changes in IL-10 production. Hum Genet 2008;124(05):515-524

38 Niu YM, Du XY, Cai HX, et al. Increased risks between Interleukin10 gene polymorphisms and haplotype and head and neck cancer: a meta-analysis. Sci Rep 2015;5:17149

39 de Oliveira JG, Rossi AF, Nizato DM, et al. Influence of functional polymorphisms in TNF- $\alpha$, IL-8, and IL-10 cytokine genes on mRNA expression levels and risk of gastric cancer. Tumour Biol 2015;36 (12):9159-9170

40 Hiroki $\mathrm{CH}$, Amarante MK, Petenuci DL, et al. IL-10 gene polymorphism and influence of chemotherapy on cytokine plasma levels in childhood acute lymphoblastic leukemia patients: IL-10 polymorphism and plasma levels in leukemia patients. Blood Cells Mol Dis 2015;55(02):168-172

41 Chagas BS, Lima RCP, Paiva Júnior SSL, et al. Significant association between IL10-1082/-819 and TNF-308 haplotypes and the susceptibility to cervical carcinogenesis in women infected by $\mathrm{Hu}-$ man papillomavirus. Cytokine 2019;113:99-104

42 Hardikar S, Johnson LG, Malkki M, et al. A population-based casecontrol study of genetic variation in cytokine genes associated with risk of cervical and vulvar cancers. Gynecol Oncol 2015;139 (01):90-96

43 Netea MG, Wijmenga C, O'Neill LA. Genetic variation in Toll-like receptors and disease susceptibility. Nat Immunol 2012;13(06): 535-542

44 Lettre G, Rioux JD. Autoimmune diseases: insights from genomewide association studies. Hum Mol Genet 2008;17(R2): R116-R121 
45 Cerhan JR, Ansell SM, Fredericksen ZS, et al. Genetic variation in 1253 immune and inflammation genes and risk of non-Hodgkin lymphoma. Blood 2007;110(13):4455-4463

46 Hamidullah CB, Changkija B, Konwar R. Role of interleukin-10 in breast cancer. Breast Cancer Res Treat 2012;133(01):11-21

47 Mocellin S, Marincola FM, Young HA. Interleukin-10 and the immune response against cancer: a counterpoint. J Leukoc Biol 2005;78(05):1043-1051
48 Wang Y, Liu XH, Li YH, Li O. The paradox of IL-10-mediated modulation in cervical cancer. Biomed Rep 2013;1(03): 347-351

49 Stanczuk GA, Sibanda EN, Perrey C, et al. Cancer of the uterine cervix may be significantly associated with a gene polymorphism coding for increased IL-10 production. Int J Cancer 2001;94(06): 792-794 